\title{
The "Crowding Out" of Private Expenditures by Fiscal Policy Actions"
}

\author{
by ROGER W. SPENCER and WILLIAM P. YOHE
}

Fiscal policy - Federal Govemment spending and taxing programs - was given the dominant role in economic stabilization efforts during the decade of the 1960 s. The income tax cut of 1964 was designed to accelerate the movement toward full employment after about three years of what was considered by some a rather slow rate of economic expansion following the recession of 1960-61. The income tax surcharge and a reduction in the rate of increase in Government spending were adopted in 1968 to curb the inflation of the last half of the $1960^{\prime}$ s.

The theoretical rationale frequently given by stabiliation officials for such relince on fiscal actions was the simple Keynesian multiplier analysis found in a large number of economic textbooks. The sim. ple form of the multiplier process holds that an increase in Govemment expenditures or a decrease in the rate of taxation induces repeated rounds of spending by consumers and business firms, resulting in a multiple expansion of total spending. A multiple reduction of total spending is said to result from fiscal changes opposite those just mentioned. This analysis gives little recognition to the infuence on total spending of fuancing a defict, or disposing of a surplus, by altering the amount of Government borrowing from the general public or the rate of monetary expansion.

The extent to which this analysis guided the recommendations of stabilization atthorities during the 1960's is indicated by an examination of the ANNUA. REPORTS of the President's Council of Economic Advisers (CEA). The multiplier process just mentioned played an imporiant role in shaping the CEA's view of economic stabilization and was spelled out several times in the AvvuAs. REPORTS.

The CEA's Annual Repont for 1964, Appendix A, outlined the multiplier process by which an $\$ 11$ billion tax cut would produce a $\$ 30$ billion increase in total demand. According to this outline, a tax cut of this size would first increase consumption by $\$ 9$ billion, which in turn "would generate still further increases in incomes and spending in an endless, but rapidly diminishing, chain." This would result in adding $\$ 18$ billion to GNP from increased consumption alone " - not just once, but year-in and yearout.. "But the multiplier process is not complete at this point. In response to rising income, expenditures for plant and equipment, inventories, residential construction, and state and local govemment programs would expand, and by the maltiplier process would add another "\$10 to $\$ 14$ billion to GNP." In this analysis, however, no mention was made regarding the Government financing requirements of the proposed tax reduction.

In discussing the proposed income surtax as a means of reducing inflation, the ANNuA REPORT for 1968 argued that the same multiplier process was relevant. The CEA asserted, ".. the eco" nomic effects of a tax increase are the mirror-image of the expansionary effects accomplished by tax reduction."

The view that changes in Government expenditures and tax fates exercise a powerful influence on total spending, without regard to changes in the volume of Government debt outstanding or in the rate of monetary expansion, has also been prevalent among many others. About four hundred professional economists signed a statement supporting the Revenue Act of 1964 as a means of stimulating total demand. Politicians, public frgures, and economic commentators have come generally to support fiscal actions explicitly, but more freguenty implicitly, on the basis of the simple multiplier analysis.

This view has been challenged by a number of economists on the grounds that if does not give adequate recognition to the financing of Govemment expenditures. They argue that Government spending financed by taxes or borrowing from saving of the general public may reduce other spending to such an extent that there will be litte, if any, net increase in total spending. This is frequently referred to as the "crowding out" of private expenditures by fiscal actions. According to these economists, stabilization recommendations based on the prevailing multiplier analysis of the $1960^{\circ}$ are erroneous.

The following article by Roger $W$. Spencer and Willam $P$. Tohe provides a survey of economic theory from Adam Smith to the present regarding the influence of fiscal actions on economic activity. Thet find that "crowding out" has been the dominant view during the past two hundred years. Moreoter, the emphasis, on the simple Keynesian multiplice analysis in developing economic stabilization programs during the $1960^{\prime}$ s is not in general agreement with Keynes' own views or with post-Keynesian economics.

Roger W. Spencer is an economist of the Federal Reserve Bank of St, Louis. Willam P. Yohe is Professor of Economics at Duke Unwersity and was a visiting scholat at the Federal Reserve Bank of St. Louis for a period of time in 1969 and 1970. 
Fiscal policy provides additional spending in a world of sparse spending opportanities. But it does not provide a new source of finance in a world where spending is constrained by sources of france. The govemment expenditures are financed in debt markets in competition with private expenditures. The case least favorable to fiscal policy is that in which the additonal govemment borrowing simply CROWDS OUT of the maket an equal (or concewably even greater) volume of bortoting that would have financed private expenditures. (Italios and capitalizalion added)

Changes in Government expenditures and taxes, the policy arm of Keynesian economics, have come under attack recently for their apparent failure to secure desired stabilization goals. Several studies, in this Review and elsewhere, have concluded that increases in Govermment expenditures, which are not accompanied by money creation, induce temporary increases in nominal GNP with no net effect over a longer period of time." Monetary actions, in contrast, have been found to exert an important influence on economic activity quite apart from fiscal developments. Wuch of the rebuttal of these articles has been focused on debating the strengths of the monetary variables rather than the weaknesses of the fiscal variables."

*The authors wish to acknowledge the helpful comments on earlier drafts of: Leonall C. Andersen, Karl Brtmner, Keith M. Cartsom, E. G. Corrigan, John M. Culbertson, R. Atton Gibert, Thomas M. Havrilesky, Jerry L. Jordan, Michael W. Keran, Laurence H. Meyer, and Clark $A$. Warburton. The authors are solely responsible for the analysis and concliw sions presented in the article.

1 Tohn M. Culbertson, Macroconomic Theory and Stabilization Policy (New York: McGraw-Fill Book Gompany, 1968), p. 463.

"Leonall C. Andersen and Jerry L. Jordan, "Monetary and Fiscal Acbons: A Test of Their Relative Importance in Economic Stabilization," this Review (Novenber 1968); Leonall C. Andersen and Keith M. Carlson "A Monetarist Model for Economic Stabilization," this Review (April 1970); Michael W. Keran, "Monetary and Fiscal Influenes on Economic Activiry - The Historical Evidence," this Review (November 1969), and "Monetary and Fiscal Influences on Economie Activity - The Foreign Experience," this Review (February 1970) ; John Deaver, "Monetary Model Building," Business Economics (September 1969). Also, in this vein, see Milton Friedman and David Meiselman, "The Relative Stability of Monetary Velocity and the Investment Multiplier in the United States, 1897-1958," in Stabilization Polictes, Commission on Money and Credic (Englewood Clifs, N.J.: prentice-Hall, Fno, 1963 ).

3The monetary variables nost often emploved in these aricles are changes in money and the monetary base. The primary fiscal spending variable is changes in high-employment Government expenditures. For a defense of the fscal position, see Murray Weidenbatum, "Is Fiscal Policy Dead?" Financial Analysts Joumal (March-Apri, 1970) and E. G. Corrigan," The Measurement and Importance of Fiscal Policy Changes," Federal Reserve Bank of New York Monthly Review (June 1970).
This article surveys a large body of economic literature, in search of some reasonable rationale which could explain the poor showing of the Government spending multipliers in the previously mentioned re. duced-form statistical studies. Two possible reasons why these multipliers fail to achieve the high magnitudes promised by a mathematical derivation of the basic "Keynesian" multiplier are that many Keynesian models do not capture (1) the displacement of private spending by Govemment spending (the "crowding-out" effect), or (2) leakages associated with consumer or Govermmental propensities to spend. The leakages are usually accounted for in the more sophisticated econometric models, resulting in lower multipliers than those derived from the elementary models, but failure to allow for the possibility of crowding out makes even these multipliers higher than warranted.

Worldwide acceptance of the Keynesian theory, and increasing Govermment intervention in economic affairs, represent the trend of post-depression thinking on stabilization policy.* There seems to be a growing belief, however, that fiscal policies developed and applied in a society operating at a low level of resource utilization are not necessarily applicable under high. employment, inflationary conditions. Further, the evidence presented by one analyst casts doubt on the efficacy of fiscal policies even during the deflationary $1930^{\prime} \mathrm{s} . \overline{\mathrm{s}}$

Pure fiscal actions, which entail changes only in Govemment expenditure and tax prograns, are rare; most stabilization actions involve a mixture of (1)

4 See, for example, Robert Lekachman, The Age of Ketnes (New York: Random House, 1966). The diffenlty of gen eralizing "Keynes' view" or "the Keynesians" wiew" has been pointed out by Axel Leiponherve "Keynes and the Keynesians: A Singgested Interpretakion," American Fconomic Revew, May 1967 , Papers and Proceedings, p. 401).

One must be carefil in applying the epthet 'Keynesian' nowadays. I propose to use it in the broadest possible sense and let 'Keynesian economics' be synonynous with the "majority school macroecononics which has evolved out of the debates triggered by Keynes's General Theory ....

Within the majority school, at least two major factions Wve in recently peaceful but nonetheless unensy coexistence. With more brevity than accuracy, they may be labeled the 'Revolutionary Orhodoxy' and the 'Neoclassical Resurgence'. . . . The orthodoxy tends to slight monetary in favor of fiscal stabilization policies. The neoclassical faction may be suffciently characterized by negating these statements. As described, the orthodoxy is hardly a very reputable position at the present time. Its infuence in the currently most fashionable felds has been steadily diminishing, but it seens to have found a refuge in business cycle theory and, of course, in the teaching of undergraduate macroeconomics.

5Keran, "Monetary and Fiscal Influences on Economic Activity - The Historical Evidence," p. 23. 
fiscal (tax-financed Govemment spending), (2) mone* tary (Federal Reserve actions) and (3) debt management (changes in the maturity or value of the debt) policies. For example, the offering of Treasury bonds to finance a deficit constitutes debt management policy (or fiscal policy, by more conventional definitions) at first, but the subsequent purchase of such bonds (or perhaps the failure to purchase such bonds) by the Federal Reserve is generally construed to be monetary policy. Thus the existence of Government bonds clouds the distinction between the two basic economic stabilization policies - monetary and fiscal.

The method of financing Govemment expenditures influences economic stabilization efforts. There are two conflicting views regarding the extent of this influence. Funds for Government spending are obtained by taxing the public, borrowing from the public, and/or money creation. Monetarists (those who favor monetary over fiscal stabilization policies) generally assert that Government spending financed by either taxing or borrowing from the public is mainly a resource transfer from the private sector to the Government, with little net effect on total spending. Monetary expansion, even if unaccompanied by an increase in Government spending, has a strong, stimulative influence on the economy.

Contemporary Keynesian theory holds that all of the three techniques of Government finance involve something more than a simple resource transfer from the private to the Government sector. An expansionary effect on the economy may be achieved by a rise in Government spending matched by an increase in tax receipts, or by a rise in Government spending financed by bond issuance either to the public or the monetary authorities.

The monetarists' view that Govermment spending financed by taxes or borrowing from the public merely displaces, or "crowds out," private spending is not a new one. It was, in fact, the dominant view before the Keynesian revolution of the 1930 's. Classical economists including Adam Smith and David Ricardo, and neo-classicists including F. A. Hayek and R. G. Hawtrey, found little use for fiscal stabilization efforts. Keynes, at first a fairly orthodox neo-classical economist, altered his views on many issues prior to the publication of The General Theory of Employment, Interest and Money, including a downgrading of the fiscal crowding-out concept." Since it was Keynes"

GTohn Maynard Keynes, The General Theory of Employment, Interest and Money (New York: Harcourt, Brace and Company, 1936). His book will be referred to as The General Theory throughout the remainder of this article. theory of the proper use of fiscal policy which eventually became the dominant view, we will develop at some length Keynes' thinking on the subject. Because Keynes was strongly aware of the traditional neoclassical views on fiscal theory, he hedged his arguments more carefully than many of his successors.

Keynes' General Theory analysis, in contrast to the focus of the classical school on long-run supply factors, was oriented toward shorturun demand considerations. Both views were couched predominantly in real ( $\mathrm{ra}-$ ther than nominal) tems. Consequently, crowdingout analysis derived from either of these two approaches deals primarily with the displacement of real private spending by Government spending. ${ }^{7}$

A summary of classical, neo-classical and Keynes early views on fiscal crowding out will be presented first. Next, we will trace Keynes later fiscal views, underscoring the assumptions on which his final position was built. The subsequent section examines bondand tax-financed crowding out, based principally on a Keynesian analytical framework outlined by Richard Musgrave. Finally, we discuss altemative frameworks and some empirical evidence bearing on the crowding-out issue.

\section{Summary of Classical, Neo-Classical and Keynes' Early Views on Fiscal Crowding Out}

The mainstream of economic thought prior to the publication of Keynes' General Theory in 1936 did not favor Government spending for stabilization purposes. ${ }^{8}$ There was some opposition to an enlarged

"The crowding-out phenomenon may be described in conventional mathematical symbols in the following manner:

a) Real crowding out

$\left.\frac{d Y^{x}}{d C^{*}}\right|_{d M^{*}=0}=0$

b) Nominal crowding out $\left.\frac{d Y}{d G}\right|_{d M=0} \approx 0$

These relations imply that:

$\left.\frac{d\left(X^{*} G^{*}\right)}{d G^{*}}\right|_{d M=0} \approx-1$

or

d) $\left.\frac{d(Y-G)}{d G}\right|_{d M=0} \approx-1$

$\mathrm{Y}=$ total spending, $\mathrm{G}=$ Government spending, and $\mathrm{M}=$ money supply.

Relation (b) most closely represents the empirical crowdingout results reported in studies cited in footnote 2.

$\mathrm{C}_{\mathrm{A}}$ more detailed discussion of classical neo-classical and Keynes early views on crowding out will be presented in a fortheoming Working Paper of the Federal Reserve Bank of St. Louts. 
role for Government spending purely from a philosophical view, but much of the criticism of increased Government intervention was based on crowding-out theory.

Adam Smith, for example, opposed extensive Govemment involvement for both philosophical and crowding out reasons. For the most part, Smith (writing in 1776) considered Government labor "unproductive," and condemned the transfer of resources from the private sector, whether through taxation or borrowing. Borrowing funds from the public to finance Government spending was asserted to involve the "destruction of some capital which had before existed in the country; by the perversion of some portion of the annual produce which had before been destined for the maintenance of productive labour, towards that of unproductive labour." Smith believed that "saving is spending," because one man"s saving becomes another man's investment. Later classical economists, such as John Stuart Mill and J. B. Say, writing primarily in the first half of the nineteenth century, saw in Adam Smith's maxim a guarantee of full employment. That is, Government spending was considered unnecessary as a stabilization tool, because private investment was sufficient to utilize the funds provided by private saving.

The most elementary case for crowding out may be examined in a "Say"s Law" framework. Say"s Law is widely known as "supply creates its own demand." More specifically, if output (supply of goods and services) is determined by the behavior of profit maximizing producers, competitive labor markets, the existing stock of capital goods, and the state of technology, then relative prices will tend automatically to adjust so as to eliminate a deficiency or excess of demand. In an economy in which Say's Law is operative, attempts by the Government to increase total spending, by raising Government expenditures and financing the increasing budget by either borrowing from the public or taxation, merely induce changes in relative prices so as to reallocate the same level of real output.

The two cases - bond - and tax-financed Government expenditures - involve changes in the structure of prices (principally interest rates) to restore equilibrium at full employment, so they represent the tendency of a market economy ultimately to neutralize disturbances (in this instance budgetary

Adam Smith, The Wealth of Nations (New York: Random House, Inc., 1937), p. 878. shocks). Without the Government's presence, private propensities to spend the full-employment level of real income for either consumption or investment sum to one as a consequence of automatic price adjustments; adding a Government propensity to spend correspondingly reduces private propensities, in order to maintain total propensities to spend equaling one. ${ }^{10}$

Neo-classical business cycle theories became an important part of economic stabilization literature in the early twentieth century. One of these theories, over-investment financed by "forced" saving, was equally applicable for any sector favored over others for loan extension by the banking system. If, for example, the Covernment were to borrow from banks to finance its investment spending, the increased purchasing power of the Government would allow it to bid resources away from other sectors and, under fullemployment conditions, drive up the price level. The higher price level would serve as a deterrent to "real" consumer or private investment spending which would otherwise have taken place.

A good example of this view is found in the testimony of the English economist, R. G. Hawtrey, before the Macmillan Committee in 1930. Hawtrey denied the usefulness of Government spending, regardless of financing even under depression conditions:

On the matter of government spending [to bring England out of her stagnation], Hawtrey stated that whether the spending came out of taxes or loans from savings, the increased governmental expenditures would merely replace private expendifures. He even considered the "radical" idea of government spending out of new bank credit, but predicted that the result of such a policy would be intlationary and a threat to the gold standard, thus forcing up the bank rate of interest and causing credit contraction. Such a plan, for him, would only defeat itself, since government expenditures out of bank credit would mean the end of cheap money for free enterprise.

(Italies added)

Keynes advocated Government spending as a stimulative economic measure twelve years before the publication of The General Theory, but he attached the "rider" that such spending should be financed by monetary expansion. ${ }^{12} \mathrm{He}$ emphasized (in 1929) that

10 See, for example, Culbertson, p. 333 .
1. Lawrence R. Klein, The Keynesian Revolution (London:
The Macmillan Company, 1968), pp. $45-46$. Hawtrey's
business cycle theory was based on easy money creating
additional working capital and inducing inventory
investment.
12Roy Forbes Hatrod, The Life of John Maynard Keynes
(New York: Harcourt, Brace and Company, 1951), p. 441.
Keynes was only one of a number of economists of the

Page 15 
the central bank had the power to defeat erpansionary fiscal actions and thus ". . ensure that the expenditure financed by the Treasury was at the expense of other business enterprise." 1 " The British Treasury, however, like Hawtrey, took the position that Covemment spending, regardless of financing, simply displaced private spending.

Keynes continued to press his fiscal policy arguments in the years preceding The General Theory. but eventually downgraded the necessity of monetary expansion accompanying incrensed Govemment spending in order for such spending to have an expansionary effect. Development of the liquidity pref. erence theory of interest and the fiscal multiplier theory, particularly the latter, were the keys to Keynes ability to shift money into the background of his analysis. The liquidity preference concept led to the idea that more efficient utilization of the existing money stock (increased velocity) was encouraged by increased Government expenditures, while the mathematical formulation of the multiplier (by R. F. Kann, a student of Keynes) indicated that the increased taxes and saving generated by the rise in Govern mentwinduced income would be just enough to cover the financing of the deficit.

\section{Keynes General Theory View of Fiscal Crowding Out}

A detailed explanation of the workings of the multiplier was one of the chief contributions of The General Theory, as was the discussion of the gualifications of maltiplier analysis. The investment mutiplier (k), wrote Keynes, "tells ws that, when there is an increment of aggregate investment, income will increase by an anount which is $k$ times the increment..." The principle of the multiplier provides

Twenties and Thities who advocated governmental deficit spending to spur economic activity. Twelve University of Chicago economists, for example, rocommended deficit spending in a 1932 memorandum to a member of Congres: "Convinced that pump-priming deficts wond induce at best only temporary revival, the Chicago economists reconm mended that deficits should continue until recovery was indisputably estabished. These would be franced by selling new issues of bonds to the reserve banks or by exchanging them for bank deposits and Federal Feserve notes," See J. Ronnie Davis, "Therry Simons, the Radical: Sone Documentary Evidence," History of Political Economy, Fall, 1969 , pp. $389-90$.

135ee John Maynard Keynes, Essays in Persuasion (New York: Harcourt, Brace and Compary, 1932), p. 126.

14Keynes, The Generol Theory, p. 115. The multiplier concept may be formalized as $\Delta Y=k \Delta$ where $\Delta \mathrm{Y}$ is the change in income, $\Delta I$ is the change in investment and $k$ is the multipler. Trvestment refers to outlays on newly created plant and eguipment and housing, and additions to inventores. A similar multiplier is developed for changes in Government expenditures $(\Delta \mathrm{G})$. "an explanation of how fuctuations in the amount of investment, which are a compantively small proporthon of the mational income, are capable of generating huchations in aggregate employment and income so much steater in amplitude than theraselves."

The muttiplier concept of an increment of new investment spending being transmitted from pocket to pocket and thereby moreasing total spending by some multiple is easier to grasp intuitively than mathematcally keynes, binself senching for the proper mathe matical mionale for his deficit spending deas, was quick to seize and popularize Kahn's version. He and Kahn realized some of the linitations of their formal muitiplier theory, but the scores of articles published during the past three decades, which clarly or repadiate "the Keynesian multiplier," suggest the inadequacy of its treatment in the Generd Theory.

The significance of the multiplier may be examined from the crowding ont point of view, to the extent that the multiplier represents canal relations rather than the ex post tantology that the change in income must, by definition, equal some multplier tines the increment of investment. ${ }^{26}$ Keynes, in The General Theory, provided one of the most cogent and clear crowdingout arguments to be found. Although he wished to move money to a supporting rather than leading role in his General Theory analysis, he recognized that monetary infuences could overcome his newly developed multiplier and liquidity preference constructs.

Contrary to expressions found in the present "conventional wisdom," Keynes hedged his argumerts considerably. He pointed out that,

If, for axample, a Goverument employs 100,000 additional men on public works, and if the multi phier... is 4 , it is not safe to assume that argregate employment will nerease by 400,000 . For the new policy may have adverse roctions on imoesment in other directions. . . The method of francing the policy and the increased working cash. required by the increased emplomment and the associated rise of prices, may have the effect of increasing the rate of interest and 50 rotarding investment in oher directions, whess the monetary athority takes steps to the contrary; whilst, at he same time, the increased cost of capital goods will reduce their maxginal efficiency

\footnotetext{
15 ibid, p. 122.

16R. F. Kahn (Eomomio Joumd, 1931, p. I88) was quite aware of the oausal is. hutological nature of the equality between the increase in the rate of investment expendinte and the subscuent streams of generated saving. The equality, he wrote, "far from being the logical conseduence of summing an infinite geometrieal progression, is in realisy selfmevident in nature..."
} 




to the private investor, and this will regure an actual fall in the rate of interest 10 oflset it. ${ }^{2 \%}$

The nulliplier limitation oullined above by Keynes can be summarized within the conventional IS-LM curve framework. In the IS-LM system, a set of equations is postulated regarding propensites to spend, to save, and to hold money balances. ${ }^{18}$ The system may be reduced to two equations. One contains various combinations of income ( $Y$ ) and interest rates (r) at which investment equals saving; this is referred to as the IS curve and represents the real sector of the economy. The other ecuation contains various combinations of $\mathrm{Y}$ and $\mathrm{r}$ at which money demanded equals the money stock in existence; this is labeled the LM curve and represents the finmolal sector. The two equations nay then be solved simultaneously to detemine equilbrium values of the interest rate and income.

If the LM curve is steeply sloped as shown in part (A) of the accompanying figure, the increase in Covermment spenting reflected in the rightward shift of the IS curve affects a sharp rise in interest rates (fron

\footnotetext{
17Keynes, The General Theory, pp. 119-20. (Italics alded except for "full")

18see, for example, Gariner Ackley, Mucroconomic Theory
} (New Won: The Mamilan Company, 1961), pp. 359-98. $r_{1}$ to $\left.r_{2}\right)$ and little or no change in income $\left(\mathbb{V}_{1}\right.$ to $\left.Y_{2}\right)$. A sharply rising LM curve implies that the retarding effects of such actions on private investment are sub. stantial. Only by shifing the LM curve to the right, through montary expansion for example, will a sig. nificant rise in incone occur (from $Y_{2}$ to $Y_{3}$ ). Keynes, by mentioning this muliplier limitation, supplied a strong theoretical basis for the crowding-out thesis, and thereby shifted the discussion to a quantitative plane involving detemination of the slopes of the IS-LM curves and the substimtability of Government and private spending.

Keynes recognized a second way, based on business psychology, in which Govermment spending could crowd out private spending. "With the confused psychology which ofter prevails, the Govermment programme may, through its effect on 'confidence, increase hiquidity preference or diminish the marginal efficiency of capital, which, again, may retard other investment mless measures are taken to offser it."

is Keynes, The Generd Theom, p. 190. Damel Thoop Smith, "Is Defint Spending Practicalp", Harvand Bustness Review (Vol. 18,1939 ), no $38-9$, was partienlarly concemed abont the bisiness confidence aspect of the crowding-out thesis.

A conthued experience with deficits which do not produce sustaned recovery, as in this country, or a recent inflathin and collapse, as in continenta turopean countries, is thely to make a defict matter ror concem and anxiety, And, if there is disbelief in the benefits of a dentcit, then 
If the increase in Government spending (shown by the shift of IS to IS' in part B of Figure 1) has an adverse effect on liquidity preference, the LM curve shifts to the left (LM') and income increases only slightly from $Y_{3}$ to $Y_{2}$. If the marginal efficiency of capital is adversely influenced, this may be shown by a leftward shift of the IS curve from $1 S^{\prime}$ to IS', also $^{\prime}$ resulting in a small increase in income from $Y_{1}$ to $Y_{2}$. The magnitude of these shifts of the curves depends, of course, on the assumed response of "business confidence" to increased Government spending.

Keynes also noted a potential multiplier leakage in the hypothesized tendency of the marginal propensity to consume to diminish as employment increases. This introduces the state of economic activity as an infuence on the efficacy of the multiplier. Thus Keynes could, without reservation, recommend any sort of public works (pyramid building, wars) during periods of unemployment, "if only from the diminished cost of relief expenditure, provided that we can assume that a smaller proportion of income is saved when unemployment is greater; but they may become a more doubtful proposition as a state of full employment is approached. Furthemore, if our assumption is correct that the marginal propensity to consume falls off steadily as we approach full employment, it follows that it will become more and more trouble-

the new money spent by the govemment may well be more than offset by additional withdrawals of pricate money which would otherwise be spent. Likewise, if consumer incomes do increase immediately as a result of the deficit, busmess may anticipate that the increase is temporary and refrain from long-term commitments.

. Consumer income arises primarily out of the processes of the production and distribution of goods and services. Therefore, if private spending decreases by as many dollars as government spending increases (and it takes only a very small proportionate decrease in private spending to offset a large proportionate increase in govermment spending), then on balance there is no net increase in consumer income. Furthermore, even if there is an immediate net increase in consumer incorne, there may be enough flexibility in our economic system in the form of idle capacity, especially during a depression, to obviate any necessity of spending on capital goods to provide consumer goods. Also, if there is an actual increase in consumer income and spending but it is believed that the demand is an artificial one dependent upon a continuation of government deficits which cannot last indefnitely, business will be loath to make long-term capital conmittments. In such circumstances business at most will make up deferred maintenance, and build up inventories creating an artificial "boomlet" which is not likely to develop into a sustained recovery. This seems to have been particularly true in 1936 and 1937. (Italics added)

This analysis implies that, dependent upon the time period specifed Government spending may not only crowd out an equal magnitude of private spending but an even greater amount. The multiplier would then be negative rather than zero or positive. some to secure a further given increase of employment by further increasing investment." 20

A related leakage was that of an increase in employment which tends, "owing to the effect of diminishing retums in the short period, to increase the proportion of aggregate income which accrues to the enterpreneurs, whose individual marginal propensity to consume is probably less than the average for the community as a whole." Moreover, the impact of the multiplier might be reduced by those unemployed consumers formerly existing on negative savings, private or public, whose employment would diminish negative savings, and thereby, the marginal propensity to consume.

An additional caveat to those who would mechanistically apply the nultiplier was that, "In any case, the multiplier is likely to be greater for a small net increment of investment than for a large increment; so that, where substantial changes are in view, we must be guided by the average value of the multiplier based on the average marginal propensity to consume over the range in question."22

These multiplier modifications and many more can be found in the post-General Theory literature, ${ }^{2 n}$ but enough has been introduced here to indicate that the value of the Government spending multiplier may be positive, zero or negative. It should be pointed out that although Keynes was aware of some of the limitations of the multiplier (as demonstrated above), he did not emphasize them, partly because of his desire to put a simple rationale for Government spend-

\footnotetext{
2Neynes, The General Theory, p. 127. One implication of this analysis is that increased Government spending, for the reasons given, may not only be less effective at stimulatirg the economy near full employment than at substantialy less than full employment, bat also relatively ineffective at slowing it. 21 lbid, p. 121.

Ibid.

23See Hugo Hegeland The Multiplier Theory (New York: Augustus M. Kelley Publishers, 1966) p. 73: "The basio weakness of the multiplier theory lies in its assumptions, which in fact eiminate the real problems involved and make the theory almost a truism."

One example of post-Keynesian criticism of the mechanical application of the multiplier can be found in Gardner Ackley, "The Mituplier Time Period: Money, Inventories, and Flexibility," American Economic Review (June, 1951) pp. 350-368. Ackley notes that the existence of inventories serves as a buffer providing a potentially long and variable lag between a change in consumer expenditures and a change in production rates. An argument made by Milton Friedman is that Government expenditure increases may be viewed by consumers as adding only to transitory income (i.e., temporary income.) $\mathrm{He}$ argues that the marginal propensity to consume out of transitory income is zero. See Milton Friedman, A Theory of the Consumption Function
} (Princeton: Princeton University Press, 1957), p. 26. 
ing during the depression in the hands of the policymakers as expeditiously as possible, ${ }^{24}$

\section{A Basic Keynesian Framework for Crowding-Out Analysis}

A number of attempts were made after Keynes to spell out more formally the relationships governing the conditions under which Government spending would add to total spending or crowd out a significant volume of private spending. Richard Musgrave developed one of the most efficient frameworks for analyzing the crowding-out phenomenon of those constructed in the approximately three decades following The General Theory.ts

There are three basic sectors of the economy and three basic "effects" in the Musgrave framework.26

24The crowding-ont issue emerged in a different context in at least one of Keynes" post-General Theory essays. In Paul Davidson, "Keynes's Finance Motive," Oxford Economic Papers (March 1965), pp. $48-49$, Keynes is quoted from an April 18, 1939 letter to the London Times, in which he explains his approach to financing Government expenditutes for rearmament: "If an attempt is made to borrow them the savings which will result from the increased production of non-consumption (war) goods] before they exist, as the Treasury have done once or twice lately, a stringency in the money market must result, sirce, pending the expenditure, the liquid resources acquired by the Treasury must be at the expense of the normal liquid resources of the banks and of the public."

"asee Richard A. Musgrave, The Theory of Public Finance (New York: McGraw-Hill, Inc, 1959), pp. 526-55.

Others outlining frameworks under which crowding ont might be analyzed include Alvin $H$. Hatnsen, Monetary Theory and Fiscal Policy (New York: McGraw-Hill Inc. 1949) pp. 167-73, and Abba P. Lemer, "The Burden of the National Debt," in Income, Employment and Public Policy, Essays in Honor of Altin H. Hansen (New York: W. W. Norton and Company, Inc, 1948), pp. 255 75. Lemer, for example (p. 269), states that The sale of govemment bonds diminishes liquidity, tends to raise interest rates, and discourages investment. The government should therefore not borrow unless it wishes to bring about these deflationary effects."

20 The following is the linear form of Musgrave's basic equations:
(1) $\mathrm{Y}=\mathrm{C}+\mathrm{I}+\mathrm{G}$
(2) $\mathrm{C}=\mathrm{a}+\mathrm{c}(\mathrm{Y}-\mathrm{T})+\mathrm{wM}$
(3) $\mathrm{I}=\mathrm{d}$ - ei
(4) $\mathrm{i}=\mathrm{U} / \mathrm{M}_{\mathrm{a}} \cdot(1-\beta) / \beta$
(5) $\mathrm{M}_{\mathrm{a}}=\mathrm{M}-\mathrm{Mt}_{\mathrm{t}}$
(6) $\mathrm{M}_{\mathrm{t}}=1 / \mathrm{V} \cdot \mathrm{Y}$
(7) $\mathrm{G}=\mathrm{T}$

$\mathrm{Y}=$ income $\mathrm{C}=$ consumption, $\mathrm{I}=$ investment, $\mathrm{G}=$ Government spending, $\mathrm{T}=$ tax yield, $\mathrm{M}=$ total money

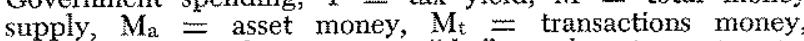
$\mathrm{V}=$ income velocity, $i=$ "the" market interest rate, $c=$ marginal propensity to consume, $w=$ a wealth parameter, $\mathrm{e}=$ an investment parameter, $\mathrm{U}=$ bond coupon bill, $\beta=$ fraction of claims (asset money and Government debt) people wish to hold in form of Government debt, $a=$ intercept term, $\mathrm{d}=$ intercept term.

The Government budget constraint, $\mathrm{G}=\mathrm{T}$, could be modified to permit deficit finance through changes in money or Government bonds. A rough approximation of the Government budget constraint for the above system of equations might take the form $\mathrm{G}=\mathrm{T}+\Delta \mathrm{M}+\Delta \mathrm{U}$.
Government, consumer, and investment spending comprise the three sectors, and income, wealth, and substitution are the three effects. Income effects are those related to changes in disposable income. Wealth effects occur with changes in the level of wealth, the ratio of wealth to income or changes in the level or structure of debt claims (money and/or Government bonds). Substitution effects result from saving or spending incentives provided by a particular Governmental tax or expenditure policy. Income and wealth effects are interdependent; the initial effect may be one or the other, but both effects become operative as the adjustment proceeds. For example, an increase in investment may occur as a result of a change in income because of a change in the propensity to invest. The income effect would be followed by a wealth effect as changes in the interest rate and the ratio of wealth to income occur over the period of adjustment.

Musgrave assumes that consumption is altered through income effects and/or wealth effects. Investment is influenced by changes in income and/or (via interest rates) changes in the level or structure of claims, while the substitution effect, which does not appear explicitly in the model, may be operative through changes in profitability due to taxation.

Wealth and income effects are seen most clearly by comparing the private sector's response to a variety of policy actions. The accompanying table illustrates a basic cataloguing of budget policies within the Musgrave framework. It gives various combinations of stabilization actions by arraying changes in the supply of Government debt against changes in the supply of money.

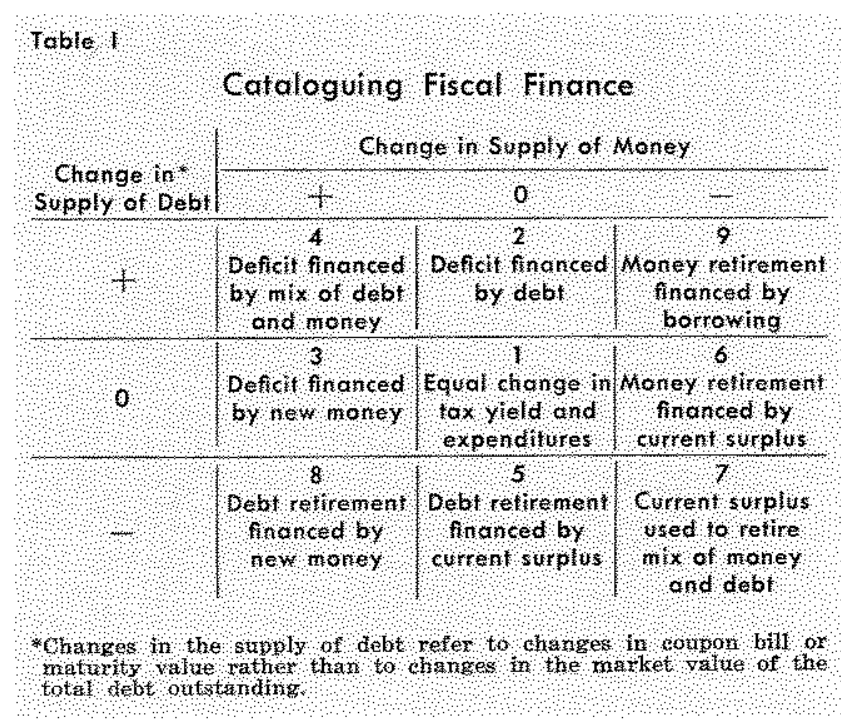


We assume that the ratio of consumption to income will increase (that is, the ratio of saving to income will fall) with increases in the supply of money, or (with some qualification) the supply of public debt and the level of investment will rise with an increase in the supply of money and will fall with an increase in the supply of debt. It is then possible to determine whether each policy mix is expansive or restrictive. Policies 3,4 , and 8 are expansionary, policies 6,7 , and 9 are restrictive, and policies 1,2 , and 5 contain ambiguous effects. Policy 2 , a deficit financed by debt issue, most closely approximates the bond-financed crowding-out case. Policy 1 approximates the tax-financed crowding-out case. Note that neither policy 1 or 2 involves changes in the sapply of money. These two cases will be examined separately, to ascertain which factors are involved in detemining whether purely budgetary actions result in an expansionary effect on the economy, or simply crowd out private spending.

\section{Bond-Financed Changes in Covemment Expendures}

What actually happens in the case of bond-financed Government expenditures depends to a large extent on the movement of the interest rate. There will be an expansionary income effect (Govemment spending adds directly to income) which may be augmented by a stimulative wealth effect on consumption (more bonds held by the public), if the interest rate remains relatively unresponsive, if the increase in the supply of Government bonds is accompanied by a sharp rise in the interest rate, the expansionary income efrect could be countered by: (1) a smaller net wealth effect (since the market value of the Govemment debt varies inversely with the interest rate); (2) displacement of private investment, which responds negatively to a rise in the bond interest rate; and (3) a diversion of funds from consumption into

wT The wealth effect, as described by Musgrave, does not consider the issue of isture tax liabilities associated with Govemment debt. Even if the interest rate responds negligibly to an increase in Covermment bonds, the vise in the value of the debt (positive wealsh effect) may be partially ofset by the discounted future tax liability required to pay the interest on the debt. The impact of the future tar liability on aggregate demand in the current period depends upon (a) the degree to which the bond-holding public considers future tax liabilities, (b) the maturity of the debt, and (c) the anticipations of the public as to the nature of the ftaterte taxes to be levied (on the incone from labor or capital) to pay the interest on the debt. See Boris $P$. Pesek and Thomas $\mathrm{R}$. Saving Monets, Wealth and Economic Theoru (New York: The Macmilan Conpany, 1967), Chapter 10, who argue that the tax liability offet to the wealth effect is only parial and not total as some analysts have suggested.
Government bond purchase (voluntary saving), hav. ing an initially restrickive effect.

The response of total spending to bond-financed Govermment expenditures is ambiguous. If savers are indifferent between the holding of bonds and money, the interest rate does not rise, the net market value of the debt increases by this means of financing, and a strong wealth effect may be realized. At the other extreme, savers insisting on holding a fixed ratio of money and debt would result in a rise in the interest rate, no change in the value of the debt (gains from the acquisition of new bonds being offset by capital losses suffered from the holding of old bonds), and no weath effect.

Actual conditions, according to Musgrave, fall somewhere in the middle. During a depression, the interest rate is likely to be relatively unresponsive. The implication is that the interest rate is likely to be most responsive during periods of rapid expansion. A more detailed model might consider the effects of price expectations and varying default risks on interest rates (and, consequently, private spending), and present a wider spectrum of private and public assets.

The introduction of fractional reserve banking (which is excluded from the above discussion) into the system complicates the argument somewhat, but the essential principles remain unchanged. In practice, as Buchanan points out, commercial bank purchases of Govemment bonds out of excess reserves permit the full expansionary effect to take place (money creation), but bonds purchased when reserves are not in excess have the same effect as borrowing from the public. In the latter case, "The expansionary effects of the public spending side of the deficit are, to a considerable extent, offset by the reduction in private investment caused by the tightening up of funds available for private securities."2s

\section{Tat Financed Changes in Government Expenditures}

The most obvious crowding out of private expenditures by Government spending, involving the involumtary transfer of hunds from the private to the Govern ment sector, is the case in which expenditures are fnanced by taxation. A balanced-budget multiplier equal to one (total spending increases by an amount equal to an increase in Government spending financed by taxes) is the usual upper limit assigned to taxfinanced Govermment expenditures. This result is

\footnotetext{
2yames M. Buchanan, The Public Finances (Homewood, 11., Richard D. Inwin, 1965), p. 99.
} 
generally deduced from the assumption that the Govermment's propensity to spend for goods and services out of tax revenue is 100 per cent, while private propensities to spend after-tax income are less than 100 per cent. ${ }^{26}$

Most simple models, including Musgraves, do not allow adequately for potential leakages from the Govemment balanced-budget multiplier, but by injecting debt considerations into the discussion of an increase in Government expenditures met by a rise in taxes, Musgrave uncovers potentially adverse influences on private spending. If an initial rise in income is generated by a balanced-budget change, a drain on asset money would develop (because of the increased transactions demand for money) which tends to have a detrimental effect on investment. The rise in income relative to a constant money supply may have a depressing effect on consumption, especially so the more the drop in net wealth (that is, a fall in the value of the debt) produced by a rising interest rate.

Most observers, however, ignore debt considerations in their analysis of the limitations of the unitary balanced-budget multiplier. The large number of assumptions necessary to the determination of a unitary balanced-budget multiplier, disregarding debt problems, reflects to some extent its implausibility. ${ }^{30}$ Baumol and Peston discuss the issue in terms of leak-

29 One observer has relied strongly on a positive balancedbudget multiplier to support his argament for the expansiveness of bond-financed Government expenditures. See Robert Eisner, "Fiscal and Monetary Policy Reconsidered," American Economic Review (December 1969), pp. 897. 905. Etsner finds Govermment expenditures, regardless of the financing, to be the controlling exogenous variable in slowing or stimulating the economy ("monetary measures are likely ultimately to be as limited in their impact in combating intlation as they have long been recognized to be limited in combating a deep depression. . . "Public works of, more generally, government investment and con sumption, teemerge in their early role as prime weapons in the arsenal against depression and take on analogous importance in any striggle against inflation," p. 904). His model shows that whether Government spending financed by bond issue is expansionary (increase in prices) or offset depends on the interest and wealth elasticities of real money and commodity demand. He presents no empirical justification for his conclusion that bond-financed Government expenditures are expansionary, but concludes that to argue against an expansion "wotld be to argue that a deficit-fnanced increase in Government expenditures can be deflationary while the same increase in Government expenditures would be inflationary if fully supported by taxes." (p. 903) His balanced-budget multiplier analysis ignores its numerous limitations as discussed above.

30James Buchanan provides a list of seven assumptions underm lying the unitary balanced-budget multiplier in The Public Finances, pp. 78-80. These are: 1) The entire amount of the Government spending change must take the form of purchases of real zoods and services currently produced 2) the balanced-budget change must be financed through taxes having about the same effects as the personal income ages from the multiplier, and conclude that, in essence, a rise in Government spending financed by taxation may crowd out an equivalent or greater magnitude of private spending. ${ }^{31}$ The basis for their reasoning is that, although the Govemment's marginal propensity to spend exceeds that of the private sector, Government spending is subject to significant leakages before its infuence on private spending is realized.

The existence of these "leakages" in a governmental tax-expenditure program - the nonredistributional effects on private consumption, the purchase of items on capital account and of goods from abroad - is, of course, well known, though no attempt seems to have been made to take account of them in the literature. Possibly some of the writers had them in mind but considered them unimportant, since presumably none of them considered the unit muttiplier figure as more than an approximation to the empirical magnitude in view of the recognized qualifications. The magnitude of the leakages may indeed be rather small, and it is very tempting to conclude that if 10 per cent of the government's balanced budget expenditure is "leaked," the multiplier will be reduced from unily to say about 0.9 . However, we argue now that fairly small leakages can even produce a negative balanced budget multiplier.

... This the multiplier will be positive, zero, or negative as the marginal propensity to save and import of the private sector is greater than, equal to, or less than $k$, the government's 'marginal propensity to leak. 32

\section{Alternative Frameworks for Analysis of the Crowding-Out Effect}

If, as has been maintained, the method by which Government spending is financed matters to both private and overall spending, it would seem that curm rent analysis should explicitly account for it in discussions of the Govemment expenditure multiplier. Quite often, however, current analysis ignores the potential crowding out of private spending when Government expenditures are financed by bond sales or taxation.

tax; 3) the public spending must not exert substiution effects on the pattern of private spending; 4) the marginal propensity to save for taxpayers must be equal to the marginal propensity to save for the suppliers of Government goods and services; 5) investment spending must not be altered significantly by the budgetary change: 6) the monetary-banking framework must permit attempted changes in spending to be carried out; 7) individual behavior in earning income must not be directly affected by the budgetary change.

3W. J. Batumol and Maurice H. Peston, "More on the Multiplier Effects of a Balanced Budget," American Economic Reviete (March 1955).

32 Ibid., pp. 144 and 145 . 
One possible reason for this oversight is that the numerous attempts to clarify the principles enunciated in Keynes' General Theory have resulted in serious oversimplification of the complete Keynesian doctrine. This oversimplification has taken place at both basic and advanced levels of economic analysis. At the basic level, the "45-degree diagrams" popularized in principles text books leave no room for budget financing considerations. ${ }^{3: 5}$ Similarly, the fundamental twoequation Keynesian model popularized in elementary text books, and its usual extensions, encourage the mechanical "cranking out" of fiscal multipliers which omit adequate treatment of the financing issue. ${ }^{34}$

The Hicksian IS-LM analysis, formulated to summarize Keynesian macroeconomic theory, represents oversimplification at a fairly advanced level (see figure 1). An increase in Government spending is demonstrated by a rightward shift of the IS curve, which, as explained above, may result in a rise in both the interest rate and income. If the analysis stops here (as it frequently does), it is difficult to discern how the increased expenditure is financed. In reality, the shift from an equilibrium to a disequilibrium position may bring about simultaneous changes in income, wealth, interest rate, money demand and money supply variables, and tax functions, depending on the source of finance. An approximation of the effects of movements in the key variables, as a new equilibrium position is established, may be achieved by altering the slopes and positions of the IS and LM curves, but the framework of analysis, without an explicit Government budget constraint, is not conducive to such shifts. ${ }^{3 \%}$

William L. Silber sets forth conditions under which Government spending can be contractionary in a properly specified IS-LM framework.36 Utilizing a framework of analysis similar to that of Musgrave, he

\footnotetext{
3s See, for exanple, Paul Samuelson, Economics, 8th edition (New York: MeGraw-Hill Book Company, Inc., 1970), p. 317 ,

iat(1) $\mathrm{C}=\mathrm{a}+\mathrm{bY}$

(2) $Y=C+I+G$

Substituting (1) into (2) and solving for $\mathrm{Y}$ gives: $Y=a / 1-b+1 / 1-b+G / 1-b$ where $\delta \mathrm{Y} / \delta \mathrm{G}=1 / 1-\mathrm{b}=$ Government spending multiplier

35"The Hicks-Hansen diagram has elegant simplicity which appeals to many. It has the disadvantage, however, that most of the "works' are out of sight. This means that we need to use another diagram (or an extra mental calculation) to determine the effect of a displacement of the equilibrium on the other variables of our system." See Ackley, p. 372 .

36William L. Silber, "Fiscal Policy in IS-LM Analysis: A Correction", forthcoming in the Journal of Money Credit and Banking.
}

finds that a rise in the supply of Government bonds which increases wealth also increases the demand for: money (represented in the IS-LM framework by a leftward shift of the LM curve). Silber concludes:

It has been demonstrated that traditional IS-L.M analysis has not treated the bond-finance and new money-finance cases of government deficits symmetrically. When proper treatment is given to the former case, we found that in the simple world of IS-LM analysis govermment expenditures financed by selling bonds to the public can be contractionary. Even when GNP does go up due to $\triangle \mathrm{G}$, the increase that occurs is overstated in the traditional (but incomplete) IS-LM model of income determination. The fallure to incorporate the monetary effects of debt finance into the LM function is the major source of confusion. While other studies have treated this question, it has rever been formally incorporated into IS-LM models. This had led to incomect conclusions regarding the multiplier affects of govemment spending.

The many income-expenditure econometric models which have emerged in the 1960 's appear to be wellsuited to handle the problems of simultaneity and the Government budget constraint. Unfortunately, some explicit provision for the fact that Government expenditures must be financed by taxing, borrowing from the public, or money creation has often been omitted from monetary and fiscal policy simulations of these large models. A model which includes, for example, Government purchases of goods and services, transfer payments, taxation, the change in the sales of Government bonds to the public, and the change in the stock of high-powered money, should be closed by the specification of the relationship between the items representing Government expenditures and the items representing Government "income."

Closure of the above system implies that in simulating the economy's response to altemative monetary and fiscal actions, it is not possible to change only one of the five variables at a time when evaluating multipliers, Carl Christ provides the following example relating Government expenditures to Government receipts:

.. if govemment purchases are increased, then either transfers must be cut, or tax payments must rise, or government debt must be issued to the private sector, or high powered money must be issued, or some combination of these. The effect of the increase in government purchases will depend upon what combination of them is chosen 37

37Carl Christ, "Monetary and Fiscal Policy in Macroeconomic Models" (Paper presented at the Sixteenth Annual Conference on the Economic Outlook, Ann Arbor, Michigan, November $14-15,1968)$, p. 102 
Thus, those models which purport to be able to say something like "A $\$ 1$ billion increase of Government purchase of goods and services results in a one-quarter increase in income of $\$ 2.5$ billion" should also make statements regarding another fiscal/monetary variable which changes in order for the statement to have meaning. With no way to determine how the $\$ 2.5$ billion increase in income is generated, it may be falsely attributed to a fiscal action when, in reality, a monetary action is responsible. That is, if changes in money are not held constant in the analysis, the estimated increase in income arising from a change in the independent fiscal policy variable may not be accurately captured. Consequently, the model would not measure accurately fiscal crowding out.

One analyst gives several examples of how, by failure to incorporate correctly the Govermment budget constraint, a number of income-expenditure models overestimate the impact of Govemment actions on income. His own reduced form empirical evidence leads him to conclude that "These results are consistent with a simple Keynesian multiplier from a deficit financed by bond purchases, with respect to the income of the private sector equal to zero." 3

Neglect of the Govemment budget constraint is not the only reason why fiscal crowding out has not appeared in some structural econometric models. If such monetary variables as money demand and supply are omitted completely from the model, the "real" sector of the economy - which normally includes Government spending actions - will, by default, dominate income changes. In terms of IS-LM analysis, omission of the LM curve (which reflects money demand and supply functions) would severely restrict the possible emergence of the crowding-out effect.

Evidence presented in this Review is consistent with the thesis that failure to identify monetary variables adequately leads to suppression of the crowding-out effect. Michael Keran found that the use of interest rates rather than monetary aggregates as monetary variables in his reduced-form equations resulted in the elimination of the fiscal crowding-out phenomenon. ${ }^{39}$ His study suggests that proper specification of monetary actions, in terms of monetary aggregates rather than interest rates, assists empirical estimators in uncovering fiscal crowding-out influences.

${ }^{3 s}$ Robert Auerbach, The Income Effects of the Govenment Deficit (Ph.D. Dissertation, University of Chicago, 1969), Appendix $A$ and p. 49.

39 Michael W. Keran, "Selecting a Nonetary Indicator - Evidence from the United States and Other Developed Countries" (this Review), September 1970.
Karl Brunner and Allan Meltzer have developed (in a preliminary paper) a framework of equations couched in terms of elasticities of interest rates, prices, wealth, and anticipations. Their approach to macroeconomic analysis, in contrast to the standard Keynesian framework, emphasizes the whole spectrum of relative price adjustments (which includes changes in the prices of goods and services as well as interest rate responses) to monetary and fiscal actions." "The role of the relative price process is particularly examined together with the responses resulting from the interaction of the asset markets. The orthodox Keynesian view of a 'reliable and direct' effect of fiscal policy on income disolves rather thoroughly. The analysis establishes that monetary and fiscal policy are equally 'indirect' and dependent on stimuli conveyed by relative price changes and adjustments in wealth positions." 41

Brunner and Meltzer believe their analysis "provides a foundation for the proposition that changes in budgetary variables (Government expenditures or taxes) exert by themselves relatively little effect on economic activity or price-levels. The crucial effect depends on the financing." They find that the Government expenditures elasticity of aggregate demand "varies between less than $1 / 5$ up to unity . .." with the higher values achieved through the injection of base money. "The pure fiscal effect of Government expenditures thus amounts to at most $1 / 5$ measured in terms of elasticities." 4 "

Even the more conventional econometric models may uncover crowding-out influences, if interest rate effects are permitted to develop over a substantial period. Private spending is curtailed over time by a rise in interest rates generated by expanded Government spending, but the result is not immediate. This

\footnotetext{
${ }^{4 t}$ Crowding out in a relative price context may be illustrated by the following simple example: If a newly-issued Goverrment construction contract enables a Government enterprise to bid against private firms for construction and other workers in a near-fully ermployed community, the private firms must raise wages to retain their workers. Those private firms losing workers will probably have to curtail output, while those retaining workers with higher wages may attempt to pass along the higher costs in the form of price increases. The higher prices would be most noticeable in the construction sector, but, with the general rise in purchasing power, onld be transmitted throughout the community. Also, the higher prices of residential construction could cause households to shift expenditures away from housing into less expensive alternatives.

41Karl Brimer and Allan Meltzer, "Fiscal and Monetary Policy in a Non-Keynesian World," (paper prepared for private circulation), p. 6 .

ylbid., pp. 57 and 57 a.
} 
is particularly true of corporations whose decisions to invest are based on the economic chmate which exists well before actual outlays are made. The specification of the lags involving interest-sensitive private spending plans may play a strong role in determining the time lag necessary for crowding out to occur.

The FRB-MIT model, which is characterized by rather long lag structures, demonstrated complete crowding out of private spending by Govemment actions, when model simulations were tracked over a long period. "In the long run, and by this we mean a long nun of ten or fifteen years, the [FRB-MIT] model is classical in that the only permanent effect of fiscal policy is to raise prices and the transactions demand for money and, in the presence of a fixed supply of money, interest rates sufficiently to crowd out enough real private expenditures that the ultimate real income effect of Government spending is zero." +3

Fiscal crowding out emerges in the reduced form equations published in this Reviet only after a period of time, even though it is a much shorter period of time than that of the FRB-MIT model. Government spending, as measured by high-employment expenditures, exercises a strong influence on GNP (assuming a constant money supply) in the current quater and the next quarter, but the Govemment spending effects wash out over approximately a one. year period. These results should not be interpreted to suggest that "Goverment spending doesn't matter." It matters very much over a certain period. Moreover, if Govemment spending were to accelerate rapidly rather than be held to a once-and-1or-all increase, the impact on GNP would be considerable over the period of acceleration and somewhat beyond.

\section{Conclusion}

A number of plausible theories have been developed over the years which substantiate the view that Government expenditures, depending on the source of finance, may crowd out a roughly equivalent magntude of private expenditures. This view, in fact, was the dominant classical and neo-classica view, persisting at least until the publication of Keynes General Theory.

Keynes himself discussed crowding out in detail in The General Theory. He indicated that the fiscal

4aEdward Gramlich, "Recent Experience with the FRBMTT Model" (patper presented to the Committee on Banking and Credit Policy, New York, November 6, 1969), p. 6. multiplier might not generate the increases in emm ployment given by a mechanical manipulation of the fquations centering on his consumption function, because of the restrictive assumptions upon which his equations were based. Keynes noted several factors tending to offset the influence of increased Govemment expenditures: possible adverse reactions on private investment, "confused" business psychology, and a tendency of the marginal propensity to consume to decline with rises in employment.

A significant number of additional limitations to the Keynesian multiplier have been pointed out in the post-General Theory literature. One of the most serious deficiencies of the fiscal multiplier appears to be its asymmetry; that is, the crowding out of private spending is theoretically more likely at full-employment than at considerably less than full-employment conditions. Since the unemployment rate has rarely exceeded seven per cent in the past three decades, compared with an average memployment rate of 18 per cent in the 1930 s, the crowding-out effect has probably been much stronger in recent years than during the period in which Keynesian multiplier theory was developed.

Wealth, income, and substitution effects, important factors in the determination of the degree of crowding out, are often incorporated in econometrie models, but failure to impose the Government budget constraint or treat adequately the monetary variables in the system of equations probably has led to understatement of the crowding-out effect.

More research on the time interval of crowding-out infuences should be conducted to improve stabilization policy recommendations. Articles published in this Review suggest that Government expenditures financed by taxes or borrowing from the public are important over a very short period, but their tendency to crowd out private expenditures obviates any significant, lasting influence. This conclusion is supported by other research, which indicates that crowding out does indeed occur, bat over a much longer time period. 粮 These results suggest that the main dispute regarding the crowding out effect centers on the length of time involved. The rationale and some empirical verification of the existence of crowding out have been established - precise relationships and time periods remain a subject of further research.

tallid.

This article is available as Reprint No. 60. 